\title{
大気圧低温プラズマを用いて作製した $\mathrm{ZnO}$ 薄膜への ヘリウムと酸素のプラズマによる表面処理*
}

\author{
馬 䀘 媛 ${ }^{* *}$ 藤 堂 卓 也*** 須 崎 嘉 文 $^{\dagger}$ \\ Helium and Oxygen Plasma Treatment on $\mathrm{ZnO}$ Thin Films Fabricated Using Atmospheric Cold Plasma \\ Xiaoyuan MA, Takuya TODO and Yoshifumi SUZAKI
}

\begin{abstract}
Under atmospheric pressure, homogeneous non-equilibrium barrier discharge was generated stably using high voltage pulsed power $(1 \mathrm{kV}, 20 \mathrm{kHz})$ excitation of helium and oxygen gases. Source material Zn-MOPD (2-methoxy-6-methyl-3, 5-heptanedionate Zinc) was fed into this glow discharge cold plasma. Transparent uniform ZnO films about $172 \mathrm{~nm}$ of thickness were fabricated on glass slides at the substrate temperature of $400{ }^{\circ} \mathrm{C}$. In this paper, we investigate the effects of $\mathrm{He}$ and $\mathrm{O}_{2}$ plasma treatment or He plasma treatment on $\mathrm{ZnO}$ thin films. The average transmittance of as-deposited film and the films after plasma treatment was about $90 \%$ with wavelengths ranging from 400 to $800 \mathrm{~nm}$. X-ray diffraction measurement revealed that $\mathrm{ZnO}$ films had a c-axis oriented poly-crystalline structure. Their crystallinity improved by plasma treatment. By increasing the time of $\mathrm{He}$ and $\mathrm{O}_{2}$ plasma treatment, electrical resistivity increased from $0.50 \Omega \mathrm{m}$ to $7.9 \Omega \mathrm{m}$ at $60 \mathrm{~min}$. However, by increasing the time of He plasma treatment, electrical resistivity decreased into $0.053 \Omega \mathrm{m}$ at $60 \mathrm{~min}$. FE-SEM observations show a change in the grain size of the columnar microstructure of the film. These results suggest that $\mathrm{He}$ plasma treatment or $\mathrm{He}$ and $\mathrm{O}_{2}$ plasma treatment change the microstructure of the film and then electrical resistivity changes.
\end{abstract}

Key words: zinc oxide thin film, plasma treatment, atmospheric pressure, cold plasma generator, poly-crystalline structure

\section{1. 緒言}

一般に, 太陽電池や液晶ディスプレイなどの透明電極として は，スズドープ酸化インジウム（ITO）の薄膜が用いられる. しかしながら，希少金属を含むこと，および，毒性をもつこと から代替え材料が求められている. その一つの候補として, 酸 化亜鉛 $(\mathrm{ZnO})$ 薄膜があげられる. 先の利用を念頭にすると, $\mathrm{ZnO}$ 薄膜にはローコスト, かつ, 大面積に成膜できる作製方法 の開発が望まれている. 一方, $\mathrm{ZnO}$ はセラミックスであり, 弾 性表面波 (SAW: Surface Acoustic Wave) デバイスなどを目的 とした圧電材料 1)として利用する場合は, その結晶性, および, 薄膜表面の $\mathrm{C}$ 軸への配向性が重要となる. さらに近年では, レ ーザー発振に $\mathrm{ZnO}$ を利用した発光デバイスとしても注目されて いる2).

薄膜の作製法の一般的な方法としては, 真空装置を用いて低 圧中でグロー放電プラズマを発生させるものが多い 314)。一方, このグロー放電プラズマを大気圧中で発生するために, 電極に 誘電体バリアを設置する方法がある. これは, 一般にアーク放 電により発生させる大気圧熱プラズマとは対照的に, 大気圧低 温プラズマとも呼ばれる. 表面改質に用いる 56) とともに, 薄膜 の作製にも利用され 334)7), 真空装置を用いないことから比較的 低コストの成膜方法として期待されている．このことはまた， 大面積への成膜を容易に行えることもメリットである. さらに この大気圧低温プラズマは約 $100{ }^{\circ} \mathrm{C}$ 以下なので, プラスチック スなどのフレキシブル基板への成膜を目標とすることもできる

* 原稿受付 平成 29 年 9 月 8 日 掍载決定 平成 29 年 10 月 17 日

** 学生会員 香川大学大学院 (香川県高松市林町 2217-20)

*** 香川大学大学院

$\dagger$ 正 会 員 香川大学工学部 (香川県高松市林町 2217-20)
と期待されている，しかしながら，低い基板温度では結晶性の 良い薄膜を得ることは難しい.

我々は, $\mathrm{He}$ ガス, および, $\mathrm{O}_{2}$ ガスを用いた大気圧低温プラ ズマを安定発生させる装置を試作し $\mathrm{ZnO}$ 薄膜の成膜に応用して いる. この際, プラズマ中の酸素が薄膜の微視組織や物性に大 きく影響する. また本装置では, 大気圧開放下でプラズマを発 生させるため, 電極周囲の大気からの酸素の影響も敏感であり, 薄膜の微視組織や物性に影響をあたえる.そこで本研究では, $\mathrm{ZnO}$ 薄膜を作製した後に大気圧低温プラズマによる表面処理を 行い, 酸素の影響により薄膜の微視組織や物性を調整する方法 を考えた. 大気圧低温プラズマのガス温度は約 $100^{\circ} \mathrm{C}$ 以下なの で、温度を上昇させない処理として特徵がある。本研究では, 成膜した $\mathrm{ZnO}$ 薄膜について, 大気圧低温プラズマによる表面処 理を行った. $\mathrm{He}$ ガスのみで発生させたプラズマ, または, $\mathrm{He}$ ガスと $\mathrm{O}_{2}$ ガスとを混合したプラズマを用いた. プラズマ処理の 前後において, 薄膜試料の透過率, および, 電気伝導率, 結晶 構造, 微視組織がどのように変化するかについて調心゙ることを 目的とした. 結晶性などの評価を容易にするため今回は基板温 度 $400^{\circ} \mathrm{C}$ で結晶性をもつ薄膜を作製することにした.

\section{2. 実 験 方 法}

図 1 に本研究で成膜に使用した大気圧低温プラズマ成膜装置 の概略を示す.プラズマ発生部には上下 $2 つ$ 平板電極がある. 上部平板電極は $\mathrm{Al}$ 製 $(50 \mathrm{~mm} \times 30 \mathrm{~mm})$ であり，中央にガス吹き 出し用のスリット穴 $(20 \mathrm{~mm} \times 1 \mathrm{~mm})$ をあけている. 下部平板電 極は $\mathrm{Cu}$ 製 $(100 \mathrm{~mm} \times 100 \mathrm{~mm})$ であり, X-Z ステージを用いて移 動、および、電極間のギャップの調整ができる.このままでは, 大気圧中でアーク放電が生じてしまうため, 下部平板電極上に 基板としてガラス $(60 \mathrm{~mm} \times 60 \mathrm{~mm}$ ，厚さ $1.0 \mathrm{~mm})$ を置くこと 


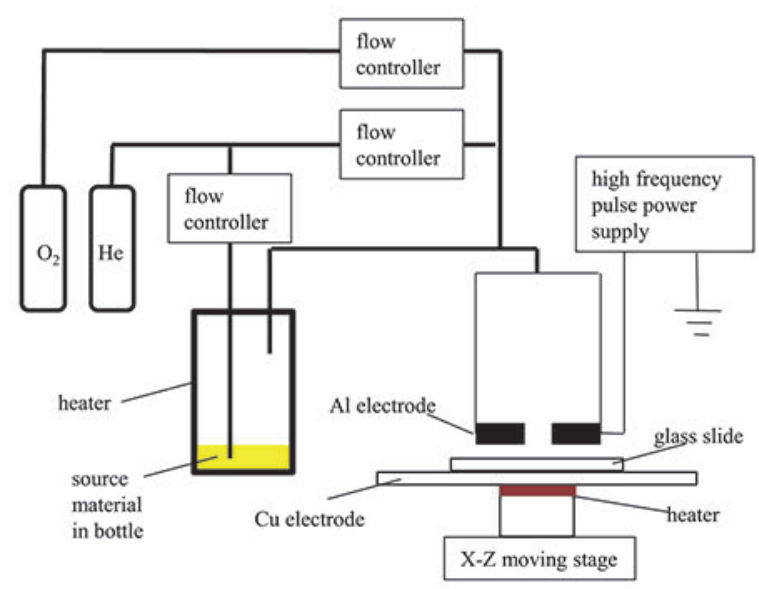

Fig. 1 Atmospheric cold plasma deposition system of $\mathrm{ZnO}$ thin films

で, このガラスが誘電体バリアの役割をしてグロー放電が発生 できるようになる. これを誘電体バリア放電とよぶ. また, ガ ス温度の高い大気圧熱プラズマに対して, 大気圧低温プラズマ に分類される. ガラス基板をのせた下部平板電極をスリット穴 に垂直な方向に往復移動 $(10 \mathrm{~mm})$ することで, 平面状の $\mathrm{ZnO}$ 薄膜を作製した.

大気圧低温プラズマは, $\mathrm{He}$ ガスと $\mathrm{O}_{2}$ ガスとを混合し, スリ ットを通して上部平板電極と下部平板電極の間に送り込み, 高 電圧パルス電源 (ハイデン研究所製, HVP-20K) を用いて励起 することで発生させた. パルス電源を用いることでグロー放電 からアーク放電に移行する前に放電を終わらせる効果もあり, プラズマを安定して発生できる. $\mathrm{ZnO}$ 薄膜の原材料として Zn-MOPD (2-methoxy-6-methyl-3, 5-heptanedionate Zinc) を用いた. 原材料は加熱, および, バブリングによって気化し He ガスをキャリアとして大気圧低温プラズマ中に導入した.

Zn-MOPD は室温で液体であり, また, 空気中において安定であ ることから取り扱いが比較的容易である. 表 1 に Zn-MOPD の 緒元を示す.

表 2 に $\mathrm{ZnO}$ 薄膜の成膜条件をまとめて示す. 原材料の $\mathrm{Zn}$ MOPD は, マントルヒーターを使用して $100{ }^{\circ} \mathrm{C}$ 加熱, 気化し た. 基板温度は $400{ }^{\circ} \mathrm{C}$ とた. 図 2 に, 以上の成膜条件によっ て得られた薄膜の概略を示す. ガラス基板上の $22 \mathrm{~mm} \times 11 \mathrm{~mm}$ の面積範囲に，透明な薄膜（厚さ $172 \mathrm{~nm}$ ）を作製できた. この 面積は上部平板電極の面積 $(50 \mathrm{~mm} \times 30 \mathrm{~mm})$ よりも小さいこと, また, 上部平板電極にあけたスリット穴が $20 \mathrm{~mm} \times 1 \mathrm{~mm}$ であり, ステージの往復移動距離が $10 \mathrm{~mm}$ であったことから, プラズマ の発生している面積全体ではなく, ガスを導入する上部平板電 極のスリット穴 $1 \mathrm{~mm}$ の直下のみ成膜されたことがわかる. その ためスリット直下における成膜速度 $\mathrm{G}$ は, 次式で表すことがで きる.

$$
\mathrm{G}=\frac{t}{T} \times \frac{D}{d}
$$

ここで, $t$ は膜厚, $T$ は成膜時間, $D$ は電極の往復移動距離, $d$ はスリットの幅である. 本条件での成膜速度は $29 \mathrm{~nm} / \mathrm{min}$ と求 められた. 膜厚の測定には表面粗さ測定装置（東京精密製, SURFCOM480A）を用いた.

薄膜試料作製後, $\mathrm{He}$ と $\mathrm{O}_{2}$ との混合ガスプラズマ, および, $\mathrm{He}$ ガスプラズマによって $\mathrm{ZnO}$ 薄膜の表面処理を行った. 表 3
Table 1 Properties of Zn-MOPD

\begin{tabular}{l|l}
\hline Zn precursor & $\begin{array}{l}\text { Zn-MOPD } \\
\text { 2-methoxy-6-methyl-3, 5-heptanedionate } \\
\text { Zinc }\end{array}$ \\
Molecular weight & 407.8 \\
Melting point & $6{ }^{\circ} \mathrm{C}$ \\
Vapor press & 0.2 torr@140 ${ }^{\circ} \mathrm{C}$ \\
Appearance & Pale yellow viscous liquid \\
Stability & Stable in air \\
\hline \multicolumn{2}{|c}{ Table 2 Deposition condition } \\
\multicolumn{2}{|l}{} \\
\hline Substrate & Glass \\
Substrate temperature & $400^{\circ} \mathrm{C}$ \\
He gas total flow rate & $1600 \mathrm{ccm}$ \\
He plasma gas flow rate & $1250 \mathrm{ccm}$ \\
He carrier gas flow rate & $350 \mathrm{ccm}$ \\
$\mathrm{O}_{2}$ gas flow rate & $10 \mathrm{ccm}$ \\
Pressure & Atmospheric pressure \\
Discharge voltage & $2 \mathrm{kV}$ \\
Power & $24.4 \mathrm{~W}$ \\
Source material & $\mathrm{Zn}-\mathrm{MOPD}$ \\
Source material temperature & $100^{\circ} \mathrm{C}$ \\
Sweep speed & $1 \mathrm{~mm} / \mathrm{s}$ \\
Anode and cathode gap & $2 \mathrm{~mm}$ \\
Deposition time & $60 \mathrm{~min}$ \\
\hline
\end{tabular}

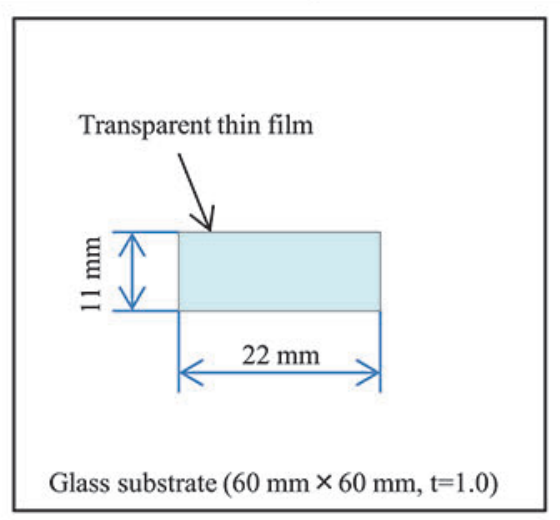

Fig. 2 Schematic diagram of typical sample

Table 3 Plasma treatment condition

\begin{tabular}{l|l}
\hline He gas flow rate & $1600 \mathrm{ccm}$ \\
$\mathrm{O}_{2}$ gas flow rate & $0,10 \mathrm{ccm}$ \\
Pressure & Atmospheric pressure \\
Discharge voltage & $2 \mathrm{kV}$ \\
Power & $24.4 \mathrm{~W}$ \\
Anode and cathode gap & $2 \mathrm{~mm}$ \\
Plasma treatment time & $15,30,45,60 \mathrm{~min}$ \\
\hline
\end{tabular}

にプラズマ表面処理の条件をまとめて示す. 成膜時と同様に大 気圧において低温プラズマを発生させた. 基板加熱は行わなか ったことから, 約 $100^{\circ} \mathrm{C}$ 以下低温での処理であったといえる. 処理時間は, $15 \mathrm{~min}, 30 \mathrm{~min}, 45 \mathrm{~min}, 60 \mathrm{~min}$ で行った.

薄膜の光学的特性の評価として, UV-Vis スペクトロメーター （島津製作所製，UV-1800）を用いて $300 \mathrm{~nm} \sim 800 \mathrm{~nm}$ の領域の 透過率を測定した. 電気抵抗率の測定は 4 端子法によって行っ た. 薄膜の結晶構造の評価は, X 線回折測定 (島津製作所製,

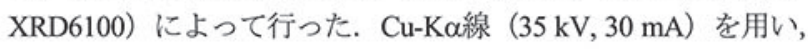
$\theta-2 \theta$ 法により測定した. 微視組織の評価のため, 高分解能走查 型電子顕微鏡（日立製作所製, S-900s）による観察を行った. 


\section{3. 結果と考察}

\section{1 大気圧グロー放電プラズマの発生}

図 3 に， $\mathrm{O}_{2}$ ガス流量，および，印加電圧を変化させた場合の 大気圧グロー放電プラズマの発生範囲について示す. 図中の 印は大気圧グロー放電プラズマの発生する最低電圧，台印はそ の最高電圧を示し，この電圧よりも高い電圧においては，プラ ズマ中にストリーマーが多数発生し，不安定なプラズマとなっ た. 例えば, $\mathrm{O}_{2}$ ガス流量; $10 \mathrm{ccm}$ の場合には, 印加電圧 ; $0.4 \mathrm{kV}$ 以上において大気圧グロー放電プラズマが安定して発生するが, 印加電圧 ; $4.7 \mathrm{kV}$ 以上においてはストリーマーが発生してしま う. Shin $5^{8}$ は, $\mathrm{He}$ と $\mathrm{O}_{2}$ の混合ガスを用いて, 本研究と同様の 条件によりグロー放電プラズマを発生させ, その発光スペクト ルの測定を行った. その結果, Oラジカル $(77.08 \mathrm{~nm}), \mathrm{He}$ ラ ジカル $(707.17 \mathrm{~nm})$ の発光ピークを得ている. また, $\mathrm{O}_{2}$ ガス流 量; $10 \mathrm{ccm}$ の時に, いずれの発光ピーク強度も強くなることを 報告している. 本研究では, 大気圧グロー放電プラズマが安定 して発生する印加電圧 ; $2.0 \mathrm{kV}$ を用い, また, 発光ピーク強度 が比較的強くなる， $\mathrm{O}_{2}$ ガス流量 ; $10 \mathrm{ccm}$ で成膜，および，プラ ズマ処理を行った. 図 4 に上部平板電極，および，下部平板電 極，典型的なグロー放電プラズマの概観を示す．プラズマは上 部平板電極の下, 下部平板電極との間の領域にのみ発生した. 図中, 移動ステージは奥行方向に往復移動させた.

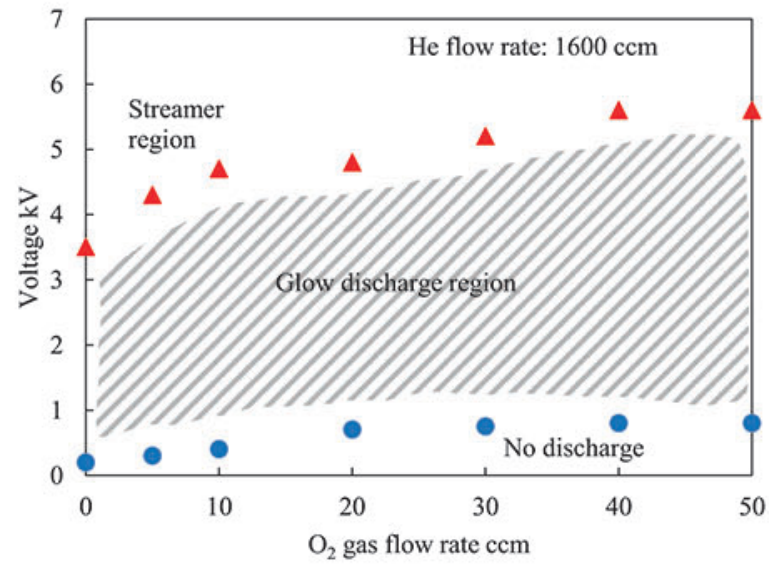

Fig. 3 Glow discharge region of the atmospheric cold plasma

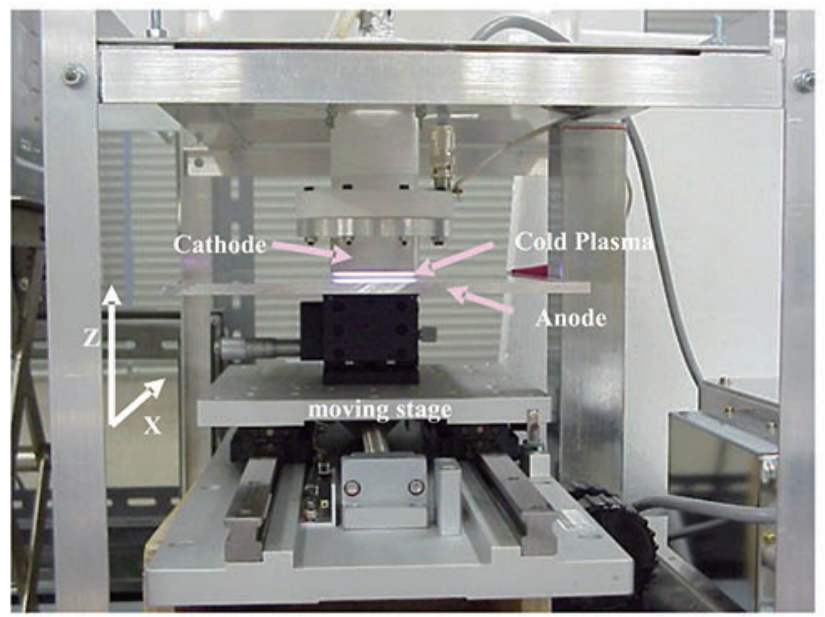

Fig. 4 Photograph of typical glow discharge

\section{$3.2 X$ 線回折測定結果}

図 5 に, 典型的な X 線回折測定結果を示す．図 $5(a)$ はプラズ マ処理前の試料, (b)は He ガスプラズマ処理 $(45 \mathrm{~min}$ ) 後の試料, (c)は $\mathrm{He}$ と $\mathrm{O}_{2}$ との混合ガスプラズマ処理 $(45 \mathrm{~min})$ 後の試料の $\mathrm{X}$ 線回折プロファイルである. どのプロファイルにおいても $\mathrm{ZnO}$ 閃亜鉛構造の(002)面のピークが钼測された.このことから，作 製された薄膜は，薄膜面が(002)面に配向した $\mathrm{ZnO}$ 薄膜であるこ とがわかった. 配向性から, 圧電材料として利用できることが 期待できる. 図 5 (b)および(c)のプロファイルにおける(002)面の ピークが, 処理前と比較して強く鋭くなったことがわかる. 図 6 に, X 線回折プロファイルにおける(002)面のピークの半值幅を 示寸. Heガスプラズマ処理によって, 半值幅は減少した. この ことから, ZnO 薄膜の結晶性が向上した，あるいは, 結晶粒径 が大きくなったことが推測できる. 一方, $\mathrm{He}$ と $\mathrm{O}_{2}$ との混合ガ スプラズマ処理によっても半值幅は減少した. どちらのプラズ マによっても結晶性の向上，あるいは，結晶粒径の増大の効果 が得られるが, He ガスプラズマの方がその効果が大きいことが 分かった.

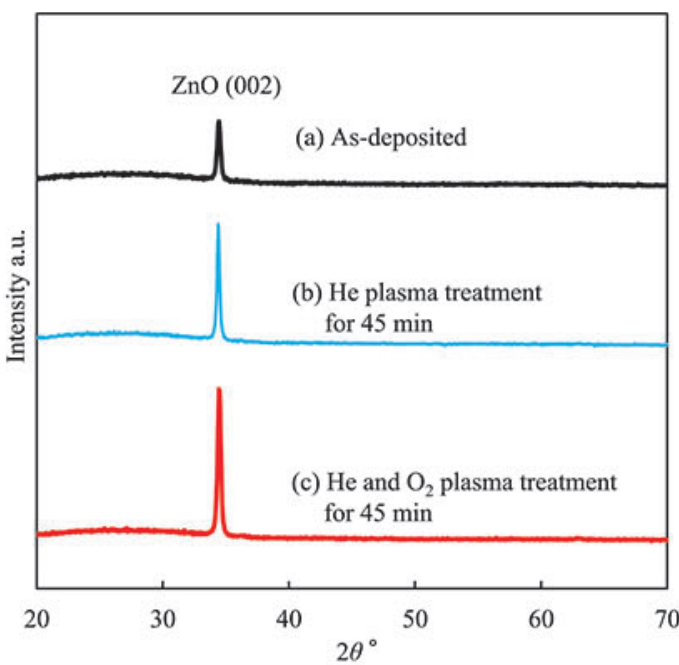

Fig. 5 Typical X-ray diffraction profiles of $\mathrm{ZnO}$ thin films

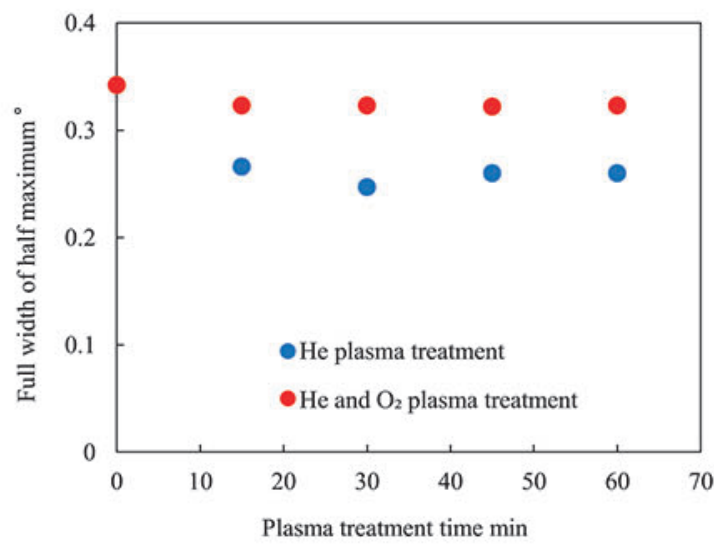

Fig. 6 Full width of half maximum of the $\mathrm{ZnO}(002)$ peak after $\mathrm{He}$ plasma treatment, and after $\mathrm{He}$ and $\mathrm{O}_{2}$ plasma treatment. 


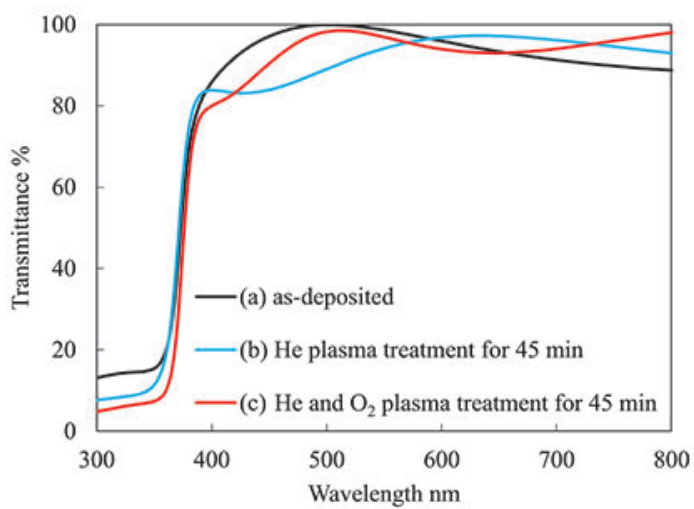

Fig. 7 Transmittance spectra of the $\mathrm{ZnO}$ thin films

\section{3 透過率スペクトル測定結果}

図 7 に, 典型的な透過率スペクトルを示す. 波長範囲は可視 光を含む $300 \mathrm{~nm} \sim 800 \mathrm{~nm}$ とした. 図7 中, (a)はプラズマ処理前 の試料, (b)は He ガスプラズマ処理 (45 min) 後の試料, (c)は $\mathrm{He}$ と $\mathrm{O}_{2}$ との混合ガスプラズマ処理 $(45 \mathrm{~min})$ 後の試料のスペク トルである. 可視光領域 $(400 \mathrm{~nm} \sim 800 \mathrm{~nm})$ の平均透過率はど の試料についても $90 \%$ 越えていた. 図 7 において, 全てのス ペクトルにおいて $370 \mathrm{~nm}$ 付近に吸収端がみられる. また, $\mathrm{He}$ ガスプラズマ処理の後, この吸収端は短波長側へシフトしてい る, このことから, He ガスプラズマ処理によって光学バンドギ ヤップが大きくなったことがわかる. 図 8 に透過率スペクトル の吸収端から計算した光学バンドギャップを示す. 青Oは Heガ スプラズマ処理の結果, 赤のは $\mathrm{He}$ と $\mathrm{O}_{2}$ との混合ガスプラズマ 処理の結果である. プラズマ処理前の試料における光学バンド ギャップの值は $3.32 \mathrm{eV}$ であった. この值は, C. Lee ら ${ }^{9}$ ，およ び, Y.Nose ${ }^{10)}$ が報告した $\mathrm{ZnO}$ の值; $3.30 \mathrm{eV}$ に近い. $\mathrm{He}$ ガスプラ ズマ処理によって, 光学バンドギャップの值は $3.35 \mathrm{eV}$ 近くまで 増加した. しかしながら, $\mathrm{He}$ と $\mathrm{O}_{2}$ との混合ガスプラズマ処理 においては, 光学バンドギャップの值の変化はわずかであった. $\mathrm{O}_{2}$ ガスを含まないプラズマ処理が光学バンドギャップを増加さ せるのに有効であるとも考えられるが, 今後他の測定方法によ ってもバンドギャップについて詳しく検討する必要がある.

\section{4 電気抵抗率測定結果}

図 9 に, 電気抵抗率の測定結果を示す. プラズマ処理前の試 料においては, 電気抵抗率は $0.50 \Omega \mathrm{m}$ であったのに対して, $\mathrm{He}$ ガスプラズマ処理 $(60 \mathrm{~min})$ を行うことで, 電気抵抗率は約一桁 減少した. この減少は, 図 6 に示した, X 線回折ピークにおけ る半值幅の減少から結晶粒径が増大したことが推測されたこと と一致した. 反対に, $\mathrm{He}$ と $\mathrm{O}_{2}$ との混合ガスプラズマ処理を行 うことで, 電気抵抗率は一析以上増加した. 図 6 に示したX $\mathrm{X}$ 線 回折ピークの半值幅はわずかに減少した. $\mathrm{He}$ と $\mathrm{O}_{2}$ との混合ガ スプラズマ処理においても若干, $\mathrm{ZnO}$ 薄膜の結晶性が向上した, あるいは, 結晶粒径が大きくなったことが推測できる. ZnO 結 晶においては, 結晶内の酸素原子の欠損によってキャリア電子 が生じる. $\mathrm{O}_{2}$ を含む混合ガスプラズマ処理によって, $\mathrm{ZnO}$ 薄膜 中の酸素欠宿が堿少したため, 電気抵抗率は増加したと推測で きる. いずれにしても, 透明電極薄膜として利用するには電気 抵抗率が高すぎるので，抵抗率を減少させる方法については, $\mathrm{He}$ ガスプラズマ処理を用いた処理についても今後さらに検討が 必要である.

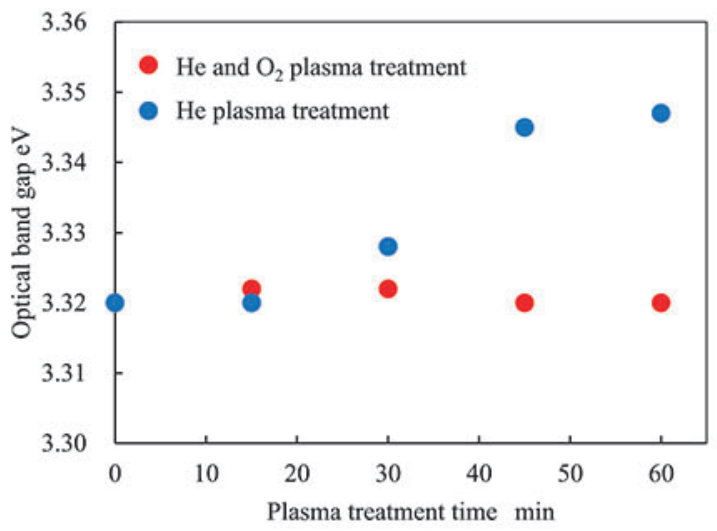

Fig. 8 Optical band gaps of the $\mathrm{ZnO}$ thin films after He plasma treatment, and after $\mathrm{He}$ and $\mathrm{O}_{2}$ plasma treatment

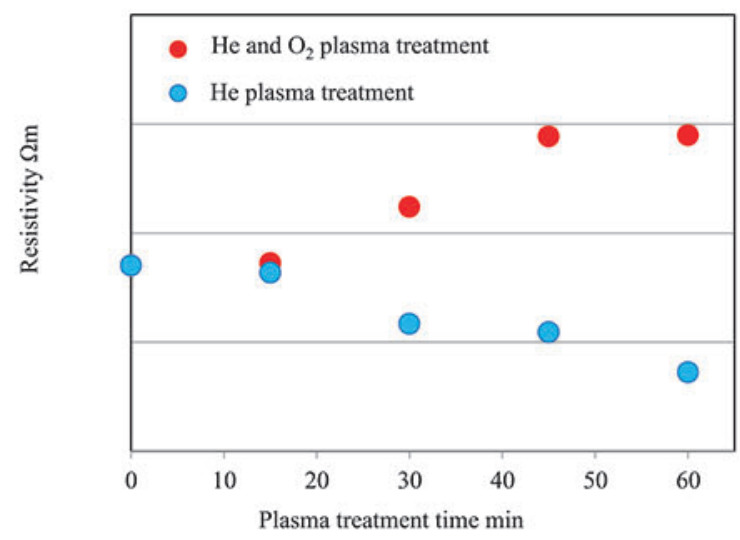

Fig. 9 Electrical resistivity of the $\mathrm{ZnO}$ thin films after $\mathrm{He}$ plasma treatment, and after $\mathrm{He}$ and $\mathrm{O}_{2}$ plasma treatment

\section{$3.5 \mathrm{Zn} 0$ 薄膜の微視構造}

図 10 に, 典型的な高分解能走査型電子顕微鏡観察を示寸. 図 10 中, (a)はプラズマ処理前の試料, (b)は He ガスプラズマ処理 (45 min) 後の試料, (c)は $\mathrm{He}$ と $\mathrm{O}_{2}$ との混合ガスプラズマ処理 (45 min) 後の試料の観察結果である. それぞれの上の図は薄膜 表面の微察, 下の図は断面の钼察である. 図 10 (a)においては, 断面観察に直径約 $30 \mathrm{~nm}$ の柱状組織がみられることから, 得ら れた $\mathrm{ZnO}$ 薄膜は，表面が(002)面に配向した多結晶構造であるこ とがわかった. また, 薄膜表面の近くにおいて, この柱状組織 が細くなった. He ガスプラズマ処理を行った図 10 (b)において は, 薄膜表面の近くの柱状組織の幅が大きくなり約 $40 \mathrm{~nm}$ とな った.この結果は, 図6に示したX線回折における(002)面の回 折ピークの半值幅が減少したことと一致する. また, 表面にお いて隣どうしがつながった.この微視組織の変化が電気抵抗率 を減少させる一因になったと考えられる. 一方, $\mathrm{He}$ と $\mathrm{O}_{2}$ との 混合ガスプラズマ処理を行った図 10 (c)においても, 柱状組織の 幅が若干増加したことがわかる.この結晶粒径の増大は, 図 6 に示した X 線回折における(002)面の回折ピークの半值幅がわず かに減少したことと一致する.

以上の結果より, 大気圧グロー放電プラズマ処理によって, $\mathrm{ZnO}$ 薄膜の柱状組織における結晶粒径が増大し, 結晶性が良く なることが分かった. ただし, その効果は, プラズマガス中に $\mathrm{O}_{2}$ ガスがある場合とない場合で異なることがわかった. 電気抵 

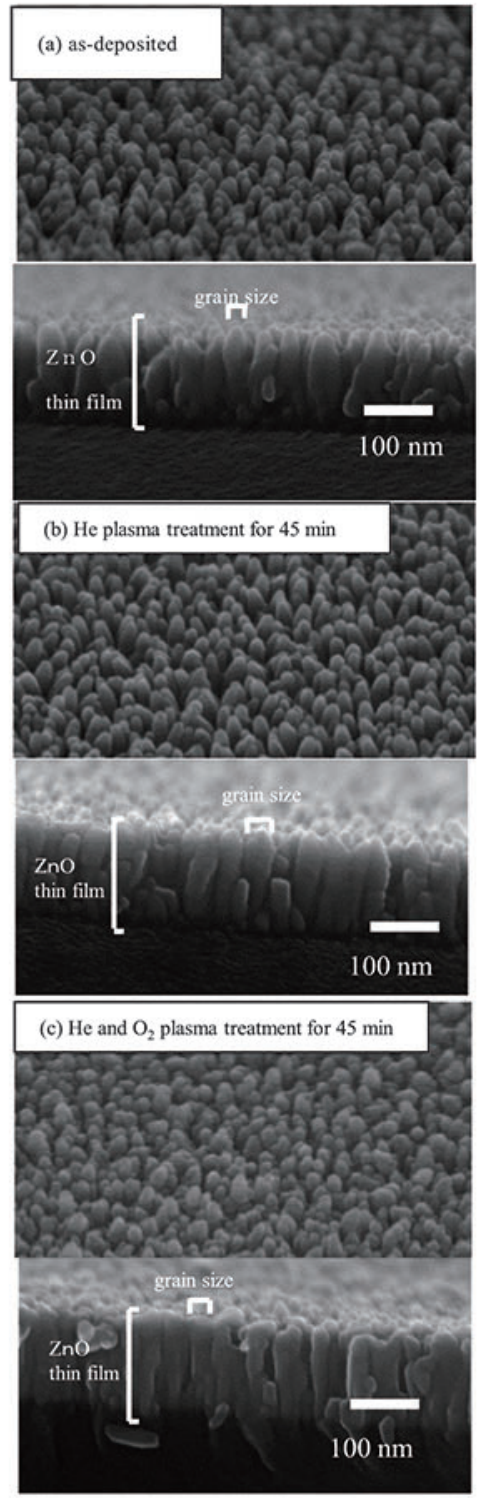

Fig. 10 Typical FE-SEM observations of (a) as-deposited $\mathrm{ZnO}$ film, (b) $\mathrm{ZnO}$ film after He plasma treatment for $45 \mathrm{~min}$, (c) $\mathrm{ZnO}$ film after $\mathrm{He}$ and $\mathrm{O}_{2}$ plasma treatment for $45 \mathrm{~min}$. Upper and below figures are surface and cross-section of the films, respectively

抗率を減少させるには， $\mathrm{O}_{2}$ ガスが無いプラズマを用いた方が良 いことがわかった.

\section{4. 結 言}

大気圧低温プラズマを用いて作製した $\mathrm{ZnO}$ 薄膜について, $\mathrm{He}$ ガスプラズマ処理, および, $\mathrm{He}$ と $\mathrm{O}_{2}$ との混合ガスプラズマ処 理を行った結果, 以下の結果を得た.

(1) 上部平板電極に開けたスリット穴の直下に, $22 \mathrm{~mm} \times 11$ $\mathrm{mm}$ の面積に, 透明で均一な厚さ; $172 \mathrm{~nm}$ の $\mathrm{ZnO}$ 薄膜を得 た. 薄膜が作製されるのは上部平板電極のスリット穴の直 下のみであり，スリット穴直下における成膜速度は 29 $\mathrm{nm} / \mathrm{min}$ と計算できた.

(2) $\mathrm{X}$ 線回折プロファイルにおいて, 閃亜鉛構造の $\mathrm{ZnO}$ 結晶の (002)面のピークのみを得た. $\mathrm{c}$ 軸に配向した多結晶薄膜を
得た. プラズマ処理によって(002)面のピークの半值幅が減 少した. 結晶粒径の増大, 結晶性の向上が得られた.この 効果は, $\mathrm{He}$ ガスプラズマ処理の方が大きかった.

(3) 透過率測定の結果, 全ての薄膜試料の可視光領域 $(400$ $\mathrm{nm} \sim 800 \mathrm{~nm})$ の平均透過率は $90 \%$ 以上であった. He ガスプ ラズマ処理によって, 光学バンドギャップは増加した. 反 対に, $\mathrm{He}$ と $\mathrm{O}_{2}$ との混合ガスプラズマ処理によって, 光学 バンドギャップはわずかに減少した.

（4）作製した $\mathrm{ZnO}$ 薄膜の電気抵抗率は $0.50 \Omega \mathrm{m}$ であった. $\mathrm{He}$ ガスプラズマ処理によって電気抵抗率は $0.05 \Omega \mathrm{m}$ まで減少 した. 反対に, $\mathrm{He}$ と $\mathrm{O}_{2}$ との混合ガスプラズマ処理によっ て, 電気抵抗率は増加した.

(5) 作製した $\mathrm{ZnO}$ 薄膜は柱状組織を示したが, 薄膜表面の近く が細くなった. He ガスプラズマ処理によって, 柱状組織の 結晶粒径が大きくなった.この微視組織の変化が, 電気抵 抗率の減少の一因になったと考えられる. しかしながら, $\mathrm{He}$ と $\mathrm{O}_{2}$ との混合ガスプラズマ処理によっても, 柱状組織 の結晶粒径が大きくなったが, 電気抵抗率は増加した.

以上の結果から, 大気圧低温プラズマを用いた表面処理を行 うことによって, 薄膜を加熱することなく微視組織を変化でき ることが分かった. また，プラズマ中に $\mathrm{O}_{2}$ ガスが有るか無いか によって, プラズマ処理の効果が異なることが分かった. プラ ズマ処理の影響は薄膜表面の近くに現れることから, 薄膜の成 長とプラズマによる表面処理を組み合すことによって薄膜の微 視組織，および，物性を制御できる可能性があるといえる.

\section{参 考 文 献}

1) M. Kadota and M. Minakata, "Characteristics of Zinc Oxide Films on Glass Substrates Deposited by RF-Mode Electron Cyclotron Resonance Sputtering System", Jpn. J. Appl. Phys., 32 (1993) 2341.

2) I. S. Yang and O. K. Kwon, "Transparent pixcel circuit with fhreshold voltage compensation using $\mathrm{ZnO}$ thin-film transistors for active-matrix organic light emitting diode displays", Jpn. J. Appl. Phys., 48 (2009) 03B024/1-03B024/5.

3) K. Haga, F. Katahira, H. Watanabe, "Preparation of $\mathrm{ZnO}$ films by atmospheric pressure chemical vapor deposition using zinc acetylacetonate and ozone", Thin Solid Films, 343/344 (1999) 145.

4) $\mathrm{H}$. K. Ha, K. Inomata and $\mathrm{H}$. Koinuma, "Plasma $\mathrm{CVD}$ of $\mathrm{SiO}_{2}$ on air-exposed surfaces by cold plasma torch", J. Electrochemical Soc., 142 (1995) 2726.

5) B. J. Lee, Y. Kusano, N. Kato, T. Horouichi and H.Koinuma, "Oxygen plasma treatment of rubber surface by the atmospheric pressure cold plasma torch", Jpn. J. Appl. Phys., 36 (1997) 2888.

6) K. Inomata, Y. Oikawa, T. Shiraishi and H. Koinuma, "Open air photoresist ashing by a cold plasma torch: catalytic effect of cathode material", Appl. Phys. Lett., 66 (1995) 2188.

7) Y. Suzaki, A. Kawaguchi, T. Murase, T. Yuji, T. Shikama, D. B. Shin and Y. K. Kim, "Effect of substrate temperature on $\mathrm{ZnO}$ thin film fabrication by using an atmospheric pressure cold plasma generator", Physica Status Solidi, C8 (2011) 503.

8) D. B. Shin, A. Kawaguchi, T. Murase, T. Yuji, T. Shikama, Y. K. Kim and Y. Suzaki, "Optical emission spectroscopy of atmospheric pressure cold plasma and fabrication of $\mathrm{ZnO}$ films", Frontier of Applied Plasma Technology, 3 (2010) 126-129.

9) C. Lee and M. Choi, "Effects of the deposition condition on the microstructure and properties of $\mathrm{ZnO}$ thin films deposited by metal organic chemical vapor deposition with ultrasonic nebulization", Thin Solid Films, 605 (2016) 157-162.

10) Y. Nose, T. Yoshimura, A. Ashida, T. Uehara and N. Fujimura, "Novel chemical vapor deposition process of $\mathrm{ZnO}$ films using nonequilibrium $\mathrm{N}_{2}$ plasma generated near atmospheric pressure with small amount of $\mathrm{O}_{2}$ below 1\%”, J. Appl. Phys. 119 (2016) 175302/1-175302/6. 